\title{
唒 $\mathrm{K} \alpha \gamma \mathrm{Q}^{1}$ \\ Kaygı Uludağ Üniversitesi Fen-Edebiyat Fakültesi Felsefe Dergisi \\ Uludağ University Faculty of Arts and Sciences Journal of Philosophy \\ Sayı 24 / Issue 24| Bahar 2015 / Spring 2015 \\ ISSN: $1303-4251$
}

\section{Research Article}

Araştırma Makalesi

\section{Metin BECERMEN}

Assoc.Prof. Dr. | Doç.Dr.

Uludağ University, Faculty of Arts and Sciences, Department of Philosophy, Bursa-Turkey

metinbecermen@yahoo.com

\section{A Study on the Criticisms about Foucault's Opinion of Power}

\begin{abstract}
In this study, will be made the evaluation of some criticisms made for Foucault's power views in the context of state and power relationship. While doing this, first of all Foucault's views about the power will be discussed shortly in this context and then the criticisms will be examined. Finally, an evaluation will be made moving from Foucault's ideas.

Foucault criticizes the viewpoints discussing the power dependent on the state. Because according to him, such kind of evaluations remains insufficient while discussing power problem. However, power has a wider and more common basis. Of course, the state has an important role in the functioning of the power; however this is not mean that power is equal to the state.

On the other hand, the power is running not only with the power of the rules but also through the norms when the law is concerned. Right runs in the context of a "game of norm". This doesn't mean that to reduce the rules to the norms or to say that the rules are insignificant in legal procedures. This, rather, emphasizes the role of norm in the law.
\end{abstract}

\section{Key Words}

Foucault, Law, Norm, Power, Right, State. 


\section{Introduction}

Foucault who discusses the power problem in broader sense and do not constrain it in an evaluation in the relationship only with the state, sees "modern state" as a developed thing over the individuals by ignoring who are and even their existences on the contrary, as a very sophisticated structure in which the individuals can be included on condition that the individuals give new format to the individualism and are subjected to a specific pattern. Thus it is possible to see the state as a modern individualism basis or a new format of pastoral power (Foucault 2005b: 66). In this context Foucault states that political, ethic, social and philosophy problem of today is not trying to save the individuals from state and the institutions of the state; but it is trying to save ourselves from both the state and the individualism connected to the state.

On the other hand, according to Foucault, reform made in criminal law is a strategy prepared to make punitive power more systematic, more effective and more permanent. The intervention purpose of the punishment is no longer to reveal the truth of the punishment; but to create an individual who is obedient and conformed to the rules, order and an authority surrounding him. On the contrary the old power types is negative and restrictive, for this new type of power is positive, productive and related to the support of life, Foucault names the new power techniques and mechanisms as biopower here. Since bio-power requires that the capitalism penetrates into the production process of the body and to make the population appropriate for economic processes, it is an indispensable element in the development of capitalism.

Foucault states that a result of the development of bio-power is an importance gained by game of norm at the expense of legal law system norm. Accordingly, law does not remain unarmed and the most suitable gun is death; it responds to the ones opposing to itself with this absolute threat at least in the final stage. The law is always thought with holy justice. However, a power that undertook life responsibility will always need regulatory and corrective mechanisms. Here, not bring forward the death in the field of sovereignty, but delivering life in the field of value and usefulness is in question. Foucault wants to state that the law is running in the form of norm more day by day and the functions of justice institution is integrating especially with a medical, administrative etc. devices universe that is regulatory a lot more gradually. According to this, a normalized society is a historical end of a power technology that centers the life (Foucault 1993: 147-8). Power relations exceed the borders of the state because first of all the state is deprived of the power to occupy all kinds of actual power relations despite the absolute power owned by its own devices and secondly, the state can run on the basis of other power relations that have already existed.

\section{Investigation of the Criticisms}

Sarup refers to Poulantzas's criticism about Foucault. Accordingly, Foucault lingers unnecessarily on the importance of discipliner techniques existing in modern state exceedingly. For this reason, he ignores the ongoing importance of generally violence, legal repression and general law. Poulantzas suggests that negative and positive values of law and state are characterized with each other equally and law does 
not only mean organizing the repression but it is the basis for reproduction. Besides, the state not only shows itself in repression and police measures, but it is quite effective in the formation of social relations and in the process of gaining the support of the mass. Poulantzas claims that Foucault deals only with oppressive and prohibitory aspects of the law and the power in other words the state deals with its positive and productive aspects and so he emphasizes the internalized oppression gained within discipliner normalization. According to him, Foucault ignores the ongoing importance of oppression matter playing a direct role in reinforcing discipliner network and ideological mechanisms and besides this, of violence problem within the activities of the state (Sarup 1995: 104). However, while Foucault is mentioning about both the state and blood society and fascism, he discusses these matters and does not violence matter. However Foucault draws the attention to another side, to the power relations. These relations also are not made in the context of a relation based on only the violence. On the contrary here, the production of the individuals is in question. The power chooses to produce the people over whom it legitimates itself instead of destroying them. Foucault, besides, states that the oppression exists in every period. However, the power cannot be understood by looking always from the perspective of oppression and violence. Otherwise, it is impossible to understand to be accepted of fascism and the similar structures; that is to say It is impossible to understand this from only violence and terror perspective. For this reason- and due to many other reasons- the says of Foucault are important.

On the other hand, Braidotti draws the attention to the fact that this world is for men and based on the men. According to him, all history of philosophy lines to manhood, masculinity and bravery mode. Bradotti states that Foucault is a man philosopher revealing that philosophic saying are determined in line with the sexual roles to a large extent. Besides being universal, he states that the philosophy bases the priority of masculine sexuality in the core on the specific gender premises regarding it as the cradle of social and political power. "In the last studies of Foucault, phallus-based system is a specific political and libidinal economy. In this sense, Foucault is a person attaining and running the definite roles of the genders for the expense of femininity" (Sarup 1995: 109). It is unnecessary to say much things about this matter, because it can be seen that there is not such emphasize with a careful reading. You must be a little "malicious" to find such a material in Foucault, because he sides against sexist attitudes rather than emphasizing the gender. Foucault deals with gender much more; in this sense he stresses on the relationship between gender and power.

According to Deveci stating that it cannot be said that the connections and the breakpoints between power relations and political power are only the problems that are discursive or related to the practices, "the politicization process of power relations is also related to the monopoly of the violence and territoriality that are the concepts that cannot be reduced at the same time to legitimacy, legal system and especially to discursive dimension. All of these four features of modern states are either ignored or reduced to the power relations in Foucault's power analysis" (Deveci 1999: 37). For Deveci, Foucault has a tendency to obey the legitimacy matter and he tends to explain social and even massive consent with taming technologies like discipline, gender and management. However, Deveci also states that in explaining common consent in 
modern societies, these technologies remain insufficient and it ignores that a rule bears not only legal norms but also moral norms forms the basis for consent. According to him, moral norms of the criminal law assumed to be accepted in the society are formed by carrying into legal norms. On the other hand, Deveci suggests that Foucault does not discuss the legitimacy of such carryings since norm phenomenon connects to direct normalization to the power indispensably because he suggests that legitimacy is also a fiction of political phenomenon like sovereignty. Deveci thinks that the decomposition of political power must not be thought as a factual situation, but as the most importanr principle related to the legitimacy. According to Deveci, the continuous variable nature of power relations in general may make impossible to live together; or installed sovereignty relations may reach to an intolerable intensity. So, in such situations, the intervention of a dissociated political power to the continuous power relations may be seen as legitimate completely by a large group of the society. However, Deveci states that a political power continuously exposed to the dynamics of power relations via asymmetrical and arbitrary way in general cannot adopt this instability for a long time and will lose its legitimacy. According to him, either it is resulted from structural effects or from the coincidences, being excluded of some clusters continuously may cause these clusters to see political power as a part of power relations. He states that the thing that is not seen in Foucault may be resulted from the fact that modern law tradition develops many institutional and legal mechanisms against such kind of confusion possibilities in time (Deveci 1999: 38). Deveci follows;

"So, as well as breaking process, modern political power will interfere power relations in general by crossing the borders and it has to make decisions and apply policies to approach the clusters that removed from itself with a strategic manner and to push a little the clusters that is approached very close to itself. Actually, the dynamism that we call as political activity are the activities performed on this border, behind the border, in front of the border different from the activities suggested to be scattered in the plurality of power relations by Foucault. Sovereignty may be excluded from a source of legitimacy but the legitimacy of modern states today may be searched in breaking principle but at the same time, in the intervention capacity of general power relations.” (Deveci 1999: 39).

Foucault sees norm society as a type of society where the power of law is including more general power not in regression. This society requires more different observation and control system. Here, an unlimited visibility, the continuous classification of an individual, making hierarchical, qualification, forming the borders and diagnosis are in question. Norm has become the standard of separating the individuals into parts. On the other hand, at the moment when the society that is being created has been a society of norm, the medicine that is the superior science of the normal and the pathological one will be the queen of the sciences (Foucault 2003: 77-8). Besides this, according to Foucault, power problem loses its importance when it is revealed only with legislative and constitutional terms or state or state devices terms. He suggests that the power is complex, intensive and common that is different from the body of laws or a state apparatus (Foucault 2003: 98). According to him, a power mechanism is wider than simple legislative and legal device and the power is applied with mush larger number of domination procedures. (Foucault 2003: 161). 
On the other hand, the state has a structure surrounding and directing all power relations. In this context, Foucault generally does not want to subject the political power to power relations and he is objected against being subjected of power relations to political power. However, Deveci tries to subordinate the power relations to political power by emphasizing on the political power. However, Foucault states that power problem must be discussed among the individuals, in a crowd, in a very complex relations network; in the narrow sense of the word, big types of political, ideological etc. power must necessarily be discussed within these relation types, I mean within the administration and inducement relations that may occur among the people; because for Foucault, if such kind of relations do not exist, other kinds of big political structures do not also exist (Foucault 2005a: 324).

According to Foucault, power is not a function of a group; on the contrary the institution is a function or a result of the power. In this sense, power does not arise from the institutions but it flows through them. The institution is only seen as an accumulation of various power relations. This accumulation is an instable accumulation since the power relations are instable and can easily turn against the institution that controls them. Besides this, when the power relations turn into dominance relations power flows can be prevented and solidified. These dominance relations form the basis of the institutions like the state (Newman 2006: 133).

Finally, it is necessary to refer to the criticisms of Baudrillard. According to Baudrillard, Foucault sees the power as an organization principle that is impossible to be reversed. While power is producing the truth, it has to produce more all the time. On the other hand, power cannot be removed in anywhere. This turns the power into a rule to be obeyed; power is the last term that cannot be reduced to anything. Baudrillard states that Foucault submits such a power trap. However, according to Baudrillard, Foucault does not see that the power has certainly disappeared (Baudrillard 1998: 54-5). On the other hand, Baudrillard says that in a place where we talk so much about the power, the power is impossible to exist (Baudrillard 1998: 78). According to him, power is a simulacrum and can be turned via the indicators (Baudrillard 1998: 54-5). Actually, Baudrillard informs against himself here because by thinking so, I mean by saying that the power is a simulacrum, he actually seems to turn the thing he called as simulacra to a simulacra. In this context, it is clear that Baudrillard does not understand Foucault as "correct"; namely, he tries to imprison Foucault within his own intellectual perspective. However, Foucault states that power exists everywhere and in all places having the power, a resistance opportunity also exists. This resistance is not also shaping a new power or power relations but to reveal the own saying of the power, a saying and game except for its own game exactly; it is to reject the saying and game of the power. On the contrary, another thing does not occur rather than turning of the subjects of this game of power into the subjects of another game of power. ${ }^{1}$

1 Actually fort he criticizes to Foucault, the following words of Deleuze are convenient: "misunderstandings are general formed by foolish responses being full of hatred. By this way, when some people discover “contradictions”, they feel smart” (Deleuze 2006: 104). 


\section{Conclusion}

Foucault states that regular and legitimate power types must be comprehended in a capillary place in the excesses and end lines instead of analyzing it in terms of the things having general mechanisms and mass effects. In other words, this is the comprehension of power from the end points that are getting increasingly less legal. Besides this, it is required not to see the power as a dominance of an individual, a group or a class over others as a molar and homogenous dominance phenomenon (Foucault 2005a: 105-6). According to him, the power having this power relations majority produces in all social relations and it exists in everywhere. Foucault draws the attention that the state device is formed by the shapes formed of the strategies describing the power by the rules or other hegemonic types and the strategies. In this context, since power can only exist when it runs, it is required to analyze its operation and in which situations it assumes the forms of domination (Foucault 2004: 10-11).

In response to the criticisms to himself, Foucault states that he never claims that power is the thing being able to explain everything. He states that the problem is not making an explanation based on the power instead of an explanation based on the economy, on the contrary, it is trying to coordinate the different analysis made on this subject and to systemize them.

On the other hand, Foucault states that the role of intellectual today is not putting the laws, suggesting solutions or foretelling, because by doing this, it contributes only to the operation of a definite power status. Foucault criticizes this situation and states that his purpose is not the explanation based on the power instead of the explanation based on the economy. He states that he has tried to organize and systemize different analysis and approaches shaped around the power problem. He also states that he cannot understand the explanations about the power imposing itself exactly and that is a general and abstract principle and the claims that he cannot explain the power. Foucault clearly says: "They say that I cannot explain it [power]. There has never been anybody saying he could!” (Foucault 2004: 156-7). 


\section{Foucault'nun İktidar Görüşü Hakkındaki Eleştiriler Üzerine Bir Çalışma}

\section{Özet}

$\mathrm{Bu}$ çalışmada Foucault'nun iktidar görüşüne devlet ile iktidar ilişkisi bağlamında yapılan bazı eleştirilerin değerlendirilmesi yapılacaktır. Bu yapılırken, öncelikle, Foucault'nun iktidara dair söyledikleri, bu konu bağlamında, kısa bir şekilde ele alınacak ve daha sonra yapılan eleştiriler irdelenecektir. Son olarak da Foucault'un düşüncelerinden hareketle bir değerlendirme yapılacaktır.

Foucault iktidarı devlete bağlı olarak ele alan görüşleri eleştirmektedir. Çünkü ona göre, bu türden değerlendirmeler iktidar sorununu ele alırken yetersiz kalmaktadır. Oysa iktidar daha geniş ve yaygın bir temele sahiptir. Devletin iktidarın işleyişinde önemli bir rolü vardır elbette; ancak bu, iktidar eşittir devlet demek değildir.

Öte yandan iktidar, hukuk söz konusu olduğunda, sadece yasaları gücüyle değil, normlar aracılığıyla da işlemektedir. Hukuk, bir "norm oyunu" bağlamında iş görmektedir. $\mathrm{Bu}$ da, yasaları normlara indirgemek veya yasaların hukuksal prosedürlerde önemsiz olduğunu söylemek demek değildir. Bu, daha çok, normun hukukta oynadığı role vurgu yapmaktır.

Foucault, düzenli ve meşru iktidar biçimlerini, genel mekanizmaları ya da toplu etkileri olabilecek şeyler bakımından analiz etmek değil; aksine iktidarı aşırıllıklarında, uç çizgilerinde, kılcallaştığı yerde kavramak gerektiğini belirtir. Başka bir ifadeyle, bu, iktidarı gitgide daha az hukuksal olan uç noktalarında kavramaktır. Bununla birlikte, iktidarı kütlesel ve homojen bir tahakküm fenomeni olarak bir bireyin, bir grubun veya bir sınıfın başkaları üstündeki tahakkümü olarak görmemek de gerekir. Ona göre, bir güç ilişkileri çokluğu olan iktidar her toplumsal ilişside üretilir ve her yerde vardır. Foucault, devlet aygıtıın, yasaların ya da diğer hegemonik biçimlerin, iktidarı tanımlayan stratejilerin kristalize olarak aldığı biçimlerden oluştuğuna dikkati çeker. $\mathrm{Bu}$ bağlamda, iktidar ancak işlediği zaman varolduğu için, onun işleyişinin analizini yapmak, hangi durumlarda egemenlik biçimlerine büründügünü saptamak gerekir.

Kendine yöneltilen eleş̧irilere karşılık olarak Foucault, iktidarın, her şeyi açılayacak şey olduğunu asla iddia etmediğini belirtir. $\mathrm{O}$, sorununun ekonomiye dayalı bir açıklamanın yerine iktidara dayalı bir açıklamayı koymak olmadığını, aksine iktidar konusunda yapmış olduğu farklı analizleri koordine etmeyi, sistemleştirmeyi denemek olduğunu söyler.

Öte yandan Foucault, günümüzde entelektüelin rolünün yasalar koymak, çözümler önermek, kehanette bulunmak olmadığını belirtir. Çünkü böyle yaptığında, sadece belirli bir iktidar durumunun işleyişine katkıda bulunmuş olur. Foucault bu durumu eleştirir ve amacının, ekonomiyi temel alan bir açıklamanın yerine iktidarı temel alan bir açıklamayı koymak olmadığını belirtir. O, iktidar sorunu etrafinda biçimlendirilen farklı analizleri ve yaklaşımları düzenlemeyi ve sistemleştirmeyi denediğini söyler. İktidarın tam anlamıla kendini dayatan, genel, soyut bir ilke olduğu ve iktidarı açıklayamadığı şeklindeki iddiaları ise anlayamadığını belirtir.

\section{Anahtar Sözcükler}

Devlet, Foucault, Hukuk, İktidar, Norm, Yasa. 


\section{REFERENCES}

BAUDRILLARD, J. (1998) Foucault'yu Unutmak, trans. Oğuz Adanır, İzmir: Dokuz Eylül Yayınları.

DELEUZE, G. (2006) Müzakereler, trans. İnci Uysal, İstanbul: Norgunk Yayınc1lık.

DEVECİ, C. (1999) “Foucault'nun İktidar Kavramsallaştırmasında Siyasal Boyutun Ayrıştırılamazlığı", Doğu Batı, sayı 9, pp. 23-39, Ankara: Doğu-Batı Yayınları.

FOUCAULT, M. (1993) Cinselliğin Tarihi I, trans. Hülya Tufan, İstanbul: Afa Yayınları.

FOUCAULT, M. (2003) İktidarın Gözü Seçme Eserler 4, trans. Işık Ergüden, İstanbul: Ayrintı Yayınları. Yayınevi.

FOUCAULT, M. (2004) Marx’tan Sonra, trans. Gökhan Aksay, İstanbul: Çiviyazıları

FOUCAULT, M. (2005a) Entelektüelin Siyasi Işslevi Seçme Eserler 1, trans. Işı ErgüdenOsma Akınhay-Ferda Keskin, İstanbul: Ayrıntı Yayınları.

FOUCAULT, M. (2005b) Özne ve İktidar Seçme Eserler 2, trans. Işık Ergüden-Osman Akınhay, İstanbul: Ayrıntı Yayınları.

NEWMAN, S. (2006) Bakuninden Lacan'a Anti-Otorieteryanizm ve Iktidartn Altüst Oluşu, trans. Kürşad Kızıltuğ, İstanbul: Ayrıntı Yayınları.

SARUP, M. (1995) Postyapısalcllık ve Postmodernizm, trans. A. Baki Güçlü, Ankara: Ark Yayınevi. 